\title{
The Effects of Collaborative Writing through Facebook on Pupils' ESL Writing Apprehension
}

\author{
Audrey Shalini Ananthan, Dr. Nur Ehsan Mohd Said
}

\begin{abstract}
The purpose of this study was to determine how using Facebook in collaborative writing effects ESL students' apprehension towards writing. A quasi-experimental study was conducted with one class of 46 year four ESL students from an urban primary school who were chosen through purposive sampling. The students were later divided into two groups: controlandexperiment.Withina9-hourengagementsessionvia

Facebook, the student were exposed to virtual collaborative writing exercises with their fellowclassmates.To gauge the level of apprehension among these students, a pre and post-test was conducted.The data were analyzed using inferential statistics as well as an analysis of the open-ended questions and interviews. The quantitative results showed that there were significant effects of using Facebook in collaborative writing on ESL students' writing apprehension level, $(M=6.27, S D=11.80), t$
\end{abstract}

$(21)=2.49, p<0.05$. However, the qualitative analysis on the interviews and open-ended responses of the questionnaires revealed both positive and negative feedback. It was also found thatthestudentshadbecomemoreawareofthebenefitsinusing

Facebook in collaborative writing and of the features of Facebook which had assisted them in their writingactivities.

Index Terms - Apprehension, collaborative writing, ESL, Facebook.

\section{INTRODUCTION}

The English Language is established in Malaysia as a second language and it is a compulsory subject in all schools bothinprimaryandsecondarylevelsasearlyasthepupilsare in Year 1. As young as 7 years old, pupils are formally exposed to all four skills, which are reading,writing,listening and speaking. These are essential skills to enable them to master English as their second language. This is an accordance to Brown who claims that an adequate exposure ofallthesefourskillswouldallowthemtobewell-proficient in the language. However, in Malaysia, apart from reading, listening and speaking, writing is considered one of the most important basic skills required especially in fulfilling the summative assessment. Writing is a skill which is developed throughprocessesandexercises.Itissaidtobeadifficulttask

(Hedge 1990; Lindemann 1982; Raimes1987). Even those who write in their native language find it is difficult to write well and express their thoughts effectively (Hedge 1990; Raimes 1983; Shaughnessy 1976). It is also a similar experience to writers who use English as their second language. According to Bryne (1979) [3] the problems faced by students who needs to perform a traditional writing task comes in three perspectives; psychological, linguistics and

Audrey Shalini Ananthan, Faculty of Education National University of Malaysia (UKM) 43600, Bangi, Selangor, Malaysia.

Dr. Nur Ehsan Mohd Said, Lecturer at Faculty of Education National University of Malaysia (UKM) 43600, Bangi, Selangor, Malaysia. cognitive. Psychologically, this task is solitary a means of communication dissimilar to speech where the speaker would get an immediate feedback from the other speaker. As referred to White (1987:260) there is "a physical separation between a writer and a reader". Therefore, the writer holds a full responsibility on the clarity of the written text. Another perspective highlighted by Bryne is also the linguistics challenge.

To be able to deliver the thoughts and message well, a proficient writer has to master the linguistic skill and rules. Nevertheless, these rules are not being much emphasized in speech. So, this contributes to apprehension. The last challenge stated is cognitive. Writing in nature is learnt through a formal instruction not just naturally acquired (Raimes 1983; White 1987). Therefore, the processes are complex. What more if it is imposed under certain conditions. As Byrne (1975, pg.5) mentions in his writing that "not only (this) has a psychological effect; it may also cause a problem in terms of content-what to say. Being loss for an idea is a familiar experience when we are obliged to write". This writer becomes more stressful when he or she has difficulty to write due to his or her inability to think and produce the content in a given duration or condition. This is also supported by Kellogg (2001) who believes that writing is not just a mean of communicating but also a major cognitive challenge and thinking process for when one writes, his thinking and act of writing are inseparable.

As for Malaysian students, English is a second language (L2) and for some in the rural areas, it may also be considered as a foreign language. Apart from the three challenges that are raised by Byrne (1979), Malaysian students are also facing the challenges of the complexity to understand the language that is not their native language (L1). This is because one may experience a language ability that is less developed compared to his native language (Schoonen et. Al, 2003). This shows how the challenges may also cause a negative barrier in pupils towards narrative writing tasks in ESL classroom.

However, this is how writing is seen traditionally as an individual task. Currently, this perspective has been given a new insight with the promotion of a student-centred approach. Collaborative learning has been given emphasis since it is believed that learners receive valuable input from others (Vygotsky 1962) and are given more opportunity for practice (Oxford 1997). One of the forms of collaborative learning is in a form of writing. Collaborative writing as defined by Storch (2005) involves several writers who produce a piece of written works and all of them contribute to all aspects of the writing; content, structure and language. The interaction which takes place in the group discussion will benefit the learners in many ways (Dale 1994; Yong 2006; 2010). These are the reasons why many educators have now started to 
employ this technique in the teaching of language in their classrooms.

In addition, the rapid evolution of today's technology becomes an interesting gateway to expand the traditional collaborative writing that takes place in the classroom. Since its introduction in 1992, internet has undergone a great leap by usage or even users especially the adolescents. In a report of a pilot study on adolescents' online activities in Malaysia by Tan et. al (2012), it was mentioned that 50 per cent of the students went online at least once or several times a day, 13 per cent did so only once in a few months and 9.3 per cent did not go on the internet at all. This is a reflection of how prospective is web-based learning are these young inquisitive people especially on their writing. Through internet too, ESL learners can be exposed to diverse and various means and sources of ESL materials. Moreover, it is also a promising platform for collaborative writing activity. Some of the prominent sites on the internet that are seen feasible in the education field are web 2.0 tools and social networks sites such as blog, wikis and Facebook. Consequently, this has roused the interest of many researchers nowadays to further find its usefulness in the language classroom application (Amir et. al 2011; Hadjerrouit 2013; Grami 2012; Ansarimoghaddam et al 2012;2013)

However, Facebook just like other social network communities such as Twitter, Wikis, Snapchat and Instagram earns more advantage for its popularity which allows users to post information, chat with others and collaborate within a system (Stelter 2008). This research aims to investigate the effect of using Facebook in collaborative writing on pupils' writing apprehension level. The research questions is 1) Is there any effect of using Facebook in collaborative writing on pupils' writing apprehension?

\section{LITERATURE REVIEW}

\section{A. Computer Assisted Language Learning (CALL)}

CALL is a term that is very close and significant to the field of modern education today where many educators are relying on for sources of materials and even used computer as a platform for communication. It was first developed in 1960s as its existence support experiential learning and practice in a variety mode, provide effective feedback to learners, enable pair and group work, promote exploratory and global learning, enhance students' achievement, provide access to authentic materials, facilitate greater interactions, individualize instructions, allow independence from a single source of information, and motive learners (Lee, 2000).

\section{B. Basic Writing Problem among Primary School Students}

In many countries worldwide, literacy skills are emphasized since early pre-school education. It goes the same with Malaysia which one of the crucial literacy skills that needed by children, are writing skills (Floyd et al., 2007; Jamian, 2011; Yunus et al., 2013). Chitravelu et al. (2005) defined writing as 'a system for interpersonal communication using the visible sign or graphic symbols on a flat surface such as paper, cloth or even stone slabs.' (p. 136). Moreover, Jamian (2011) stated that reading and writing skills are interconnected as readers able to decode the text, they also will able to encode the word which becoming the key of effective language learning. Therefore, writing is important for learners since they are able to share and express their thought and feeling in the written form.

There are previous studies discussed the issues of students' low proficiency in English language. A study by Yunus and Mat (2014) on 62 FELDA primary school pupils revealed that writing skills in the examination are the toughest skills to be mastered and the challenges faced by the teacher in order to cater their English language proficiency needs before sit the UPSR examination. This can be seen in the newspaper report on the UPSR examination result. On 2014, the pupils need to re-sit the UPSR examination for four papers and the English language is one of them (NST, 2014). This issue exposed the English language subject is a killer subject for pupils to score in UPSR examination.

Meanwhile, the former Director of Education, Datuk Seri Dr. Khair Mohamad Yusof stated there are five subjects for the last batch of KBSR syllabus have decreased in the GPMP which English language subject has affected the result for both the National School (SK) and National type School (SJK) (Awani, 2015). The decreasing of GPMP showed that primary school pupils still do not master the writing skills and have low proficiency in English language.

\section{Integrating Faceboook in Writing Learning Activities}

Facebook could be served as a platform for writing learning activities. A study by Yunus et al. (2009) found out $74.3 \%$ learners agreed that ICT could enhance their writing skills. The students felt more confident in English writing while posting ideas or comments in the Facebook. They preferred to read and write in English while communicating among them (Kabilan et. al, 2010).

Furthermore, Shih's study (2013) on the effect of integrating Facebook in the blended learning of 111 business students in Taiwanese University revealed that Facebook does improve the students' English writing skills as well as their cooperative learning with the colleagues. Facebook also could enhance their motivation and interest in learning English language. Another important finding discovered by Shih is peer assessment of Facebook group could provide a useful way in enhancing the grammar skills and the other difficult professional courses.

The other benefits of social networking service towards ESL writing learning activities are: increasing educational communication between learners and educators; expanding learners' prior knowledge as well as their vocabulary; boosting learners' confidence and motivation through interactive online English learning activities; and helping learners' writing skills via brainstorming session in the social networking (Yunus et al., 2012). This is similar to Amasha and Alkhalaf (2014) mentioned the students felt comfortable communicating in the Facebook group which allowed them to be independent in organizing their page, express their individuality and creativity. 
In addition, a study was conducted by Vikneswaran and Krish (2014) on ten Chinese students in the private urban school revealed that peer influence motivated the students to write better in English on Facebook since they exchanged feedbacks and ideas through the social networking site. Thus, ICT particularly Social Networking Services offered assistance towards the students' writing and creative thinking skills. They also claimed that they are more confident and motivated in using English language.

However, the use of Facebook in teaching and learning writing activities still has its shortcomings. The main shortcoming is learners are easily distracted by other features of Facebook such as notification, friend requesting, friend's update, games and chat box while online learning. This is supported by Kabilan et al., 2010; Yunus et al., 2012; and Karal et al., 2015 revealed participants could not focus on learning while online. One of the gaps from previous studies identified that most of the studies were centralized on secondary and tertiary education. There were not many studies on the use of Facebook in the primary level. Thus, this study intended to investigate the use of Facebook in the primary level.

\section{METHODOLOGY}

\section{A. Research Design}

This study used both qualitative and quantitative approaches. case study as defined by Stake (2005:444) is "both a process of inquiry about the case and the product of that inquiry". The objective of this study is to intensively explore its case (Stake 1995; Yin 1994) by looking into a big picture through a lens of a smaller case (Walton, 1992). Its nature enables an in-depth exploration of the assessed experience over explicit time duration on a specific group. In this case study explored by the researcher, it is important to further understand the abstract scenario of writing apprehension occurring among the low-intermediate English as Second Language (ESL) students in this urban school.

\section{B. Participants and Setting}

For the purpose of this study, purposive sampling is used to identify the respondents. The school setting is in an urban area. The respondents in this study consists of 46 students of Year Four (age 10). These students were selected based on their use of Facebook. 23 students use Facebook were chosen as the controlled group and another 23 students without Facebook. This study is also only conducted on the intermediate proficiency group of students whose level is based on their English Language proficiency scored in their English mid-term examination. Therefore, only the students who scores B, C and D in their latest English examination were selected.

\section{Instruments}

The survey instrument in this study was an adapted version of Daly and Miller (1975) tests. This instrument was first developed in the interest of research in first language learners which is the native speaker. This instrument was reported valid and reliable as the Cronbach Alpha Coefficient ranged from .89 (Daly, 1979) to .94 (Daly and Miller, 1975). The questionnaire had been sent to a TESL lecturer for validity and it was proven valid to be used in this study.

Open-ended question was provided at the end of the survey question as an additional inquiry which was believed to be able to assist the researcher to understand the feelings of the students towards the collaborative writing.

A writing assessment was conducted to gauge the students' writing proficiency. Although these students had been earlier identified as low-intermediate proficiency students based on their diagnostic test scores, the researcher needed to further confirm the students' proficiency level based on their writing. The writing test required the students to write narrative composition.

A semi-structured interview was used as triangulation of the quantitative data from the survey. This method was chosen for this data collection due to its capacity to explicitly and specifically elicit detailed information necessary for analysis across participants. Yet, it is flexible and open to allow researcher to gain more details from the participants' stories (Hill et. al., 1997). To be able to do so, probing questions were used to ensure that there is enough information on the topics covered by the semi-structured interviews and increase the researcher's understanding on the students' experiences and feelings towards writing in English.

\section{Procedures}

Phase 1: Obtaining permission from the school authorities Before conducting this survey, it is important to obtain the permission from the school's administrators. In this study, the permission was released by the headmistress of the school.

The next step was a discussion with the Head of English Panel on the purpose and the process of the study. This step was very important so that she would be able to assist the monitoring process on the implementation of this project so it may go accordingly. Teachers in this study acted as agents to create interesting and unthreatening classroom environment (Baroudy, 2008). Therefore, their monitoring and control on the class were very important to ensure a smooth process and the intervention of the online writing group as implemented as planned.

\section{Phase 2: Assigning Groups}

Since this research used a quasi-experimental approach, it comprised two groups of students namely the control group, where it uses the traditional, face-to-face approach for collaborative writing and experimental group which used an online tool, Facebook as a mean for collaborative writing. Before dividing them into groups and implementing the intervention, an independent t-test was carried out. The purpose of conducting the test was to see if the two groups were equal in the level of writing apprehension and ability to write.

Phase 3: Implementation of Collaborative Writing Activities The implementation of the intervention was scheduled to commence for about 3 months beginning August 2018 to October 2018.

\section{Phase 4: Data Collection}

The data collection in this study involved quantitative and qualitative approaches. The quantitative aspects were based on the writing apprehension score of the pre-test and post-test of WAT instrument that was conducted before and after the 
implementation of the intervention 30 that was collaborative writing via Facebook. In order for the researcher to probe into the subject matter, a collection of qualitative data from an open-ended response from students were also used to triangulate the data. These feedbacks further assisted the discussion on facts and figures of the initial data.

\section{DATA ANALYSIS}

\section{A. Is there any effect of using Facebook in collaborative writing on students' writing apprehension?}

In analysing this research question, data from quantitative and qualitative inquiries were used. The instrument used for quantitative analysis was a survey on Students' Writing Apprehension (Daly and Miller 1975) and quantitatively the researcher had used semi-structured interview and open-ended data.

i. Quantitative analysis: The Adapted Version Students' Writing Apprehension Test (Daly and Miller 1975)

In this analysis, a pre and post-test on Daly and Miller (1975) survey was used to analyse the data. The descriptive analysis on the survey was divided in two groups namely control and experiment group. The followings are the descriptive statistical analysis on the students' writing apprehension scores according to the groups.

\section{Control Group}

Table 1 Frequency of students' writing apprehension level in the pre-test and post-test of control group

\begin{tabular}{|l|l|l|l|l|}
\hline \multirow{2}{*}{$\begin{array}{l}\text { Level of } \\
\text { Writing } \\
\text { Apprehension }\end{array}$} & Pre & Post \\
\cline { 2 - 5 } & $(\mathrm{n}=19)$ & $\%$ & $(\mathrm{n}=19)$ & $\%$ \\
\hline High & 7 & $\mathbf{3 6 . 8}$ & $\mathbf{1 1}$ & $\mathbf{5 7 . 9}$ \\
\hline Moderate & 12 & 63.2 & $\mathbf{8}$ & 42.1 \\
\hline Low & - & - & - & - \\
\hline Total & 19 & 100 & 19 & 100 \\
\hline
\end{tabular}

Based on table 1, we could see that most of these students had a moderate level of apprehension (63.2\%). However, the number of highly apprehensive students increased by $21.1 \%$ after the intervention. Nevertheless, after the implementation of the intervention, the highest apprehension score was 39 whereas the lowest apprehension score was 79. This indicated that overall result showed that more than half of the group experienced higher apprehension level after the intervention.

To be able to see the significant effects of traditional collaborative writing on the students' writing apprehension, a t-test was used to analyse the difference between their writing apprehension pre-test and post-test scores. The results were as seen in table 5

Table 2 T-test results on control group writing apprehension mean scores

\section{Std. $\quad$ Sig.}

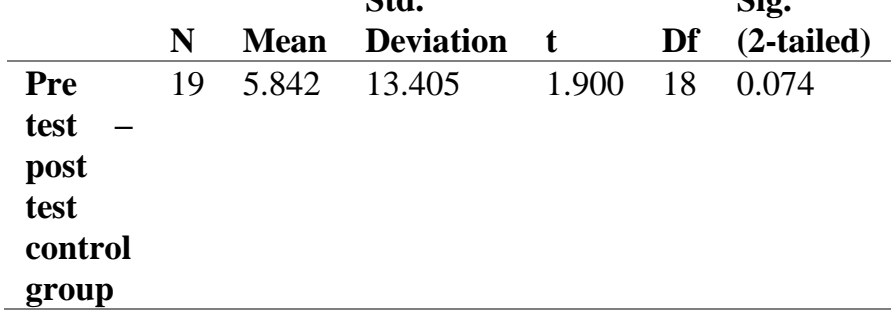

Based on the results, we can identify there was no significant difference in the mean scores of writing apprehension of the control group before and after the intervention, $\mathrm{t}(18)=1.90$, $\mathrm{p}=0.07$ (see table 4). The findings revealed that the insignificance could possibly be due to the small different in mean scores between pre and post-test. The mean of the pre-test score was 64.37 (s.d = 16.156) whereas the mean of post-test score was 58.53 ( $\mathrm{s} . \mathrm{d}=12.452)$ which illuminate not much changes occurred on the students' writing apprehension during their traditional collaborative writing assignment.

\section{Experimental Group (SS4D)}

The followings were the summary of the students writing apprehension pre-test and post-test scores in the experimental group called SS4D.

Table 3 Frequency of students' writing apprehension level in the pre-test and post-test of experimental group

\begin{tabular}{|l|l|l|l|l|}
\hline \begin{tabular}{l} 
Level of $\begin{array}{l}\text { Writing } \\
\text { Apprehension }\end{array}$ \\
\cline { 2 - 5 }
\end{tabular} & $\mathbf{n = 2 2}$ & $\%$ & $\mathrm{n}=22$ & $\%$ \\
\hline High & $\mathbf{7}$ & $\mathbf{3 1 . 8}$ & - & - \\
\hline Moderate & $\mathbf{1 5}$ & $\mathbf{6 8 . 2}$ & $\mathbf{2 0}$ & $\mathbf{9 0 . 9}$ \\
\hline Low & - & - & $\mathbf{2}$ & $\mathbf{9 . 1}$ \\
\hline Total & $\mathbf{2 2}$ & $\mathbf{1 0 0}$ & $\mathbf{2 2}$ & $\mathbf{1 0 0}$ \\
\hline
\end{tabular}

Based on the data in table 4.3, it was clear that most of the students in SS4D group experienced an average writing apprehension at the beginning of the study similar to the control group. Nonetheless, after the intervention, no students were found highly apprehensive and 2 of them experienced low-writing apprehension with the lowest apprehension score of 82. As mentioned by Daly-Miller (1975), score that falls close to the mean which is 78 showed a better level of apprehension. This clearly showed that the students' level of writing apprehension in the experiment group had tremendously improved.

In order to assess the effects of the online collaborative writing group on the students writing apprehension, a t-test was used to analysed the difference between their writing apprehension pre-test and post-test scores. Table 7 below illustrates the analysis of the t-test results.

Table 4 T-test results on experiment group writing apprehension mean scores

\begin{tabular}{|c|c|c|c|c|c|c|}
\hline & $\mathbf{N}$ & Mean & $\begin{array}{l}\text { Std. } \\
\text { Deviation }\end{array}$ & $\mathbf{t}$ & Df & $\begin{array}{l}\text { Sig. } \\
\text { (2-tailed) }\end{array}$ \\
\hline $\begin{array}{l}\text { Pre test - } \\
\text { post test } \\
\text { Experiment } \\
\text { group }\end{array}$ & 22 & 6.273 & 11.801 & 2.493 & 21 & 0.021 \\
\hline
\end{tabular}

Table 4 showed that there was a significant difference of writing apprehension in the SS4D group after the intervention, $(\mathrm{M}=6.27, \mathrm{SD}=11.80), \mathrm{t}(21)=2.49, \mathrm{p}<0.05$. The mean of pre-test score was $64.09(\mathrm{sd}=10.87)$ whereas the mean score of the training group was $57.82(\mathrm{~s} . \mathrm{d}=11.27)$ which illuminate an improvement on the students' writing apprehension level after the implementation of SS4D collaborative writing activity. 
To answer the first null hypothesis, an independent t-test was conducted to compare the differences in writing apprehension scores between the control group and experiment group. The findings are reported in table 8 below.

Table 5 Independent t-test results on students writing apprehension scores between traditional control group and experiment group.

\begin{tabular}{lllllll}
\hline & Mean & N & Std. Deviation & T & df & $\begin{array}{l}\text { Sig } \\
\text { (2-tailed) }\end{array}$ \\
\hline Control-Traditional CW & 58.53 & 19 & 12.456 & 0.191 & 39 & 0.894 \\
\hline Experiment-FB CW & 57.82 & 22 & 11.236 & & & \\
\hline
\end{tabular}

The findings in Table 5 indicated that there was no statical significant difference in the mean scores of students writing apprehension for the control group $(\mathrm{M}=58.53, \mathrm{SD}=12.456)$ and experiment group $(\mathrm{M}=57.82, \mathrm{SD}=11.236) ; \mathrm{t}(39)=0.191$, $\mathrm{p}=0.894$ (two tailed). Therefore, the null hypothesis was accepted.

Next, to answer the second null hypothesis, paired sample t-test findings are demonstrated in table 9 below;

Table 6 T-test results on training group writing apprehension mean scores between pre-test and post-test

\begin{tabular}{lllllll}
\hline & Mean & N & $\begin{array}{l}\text { Std. } \\
\text { Deviation }\end{array}$ & t & df & $\begin{array}{l}\text { Sig. } \\
\text { (2-tailed) }\end{array}$ \\
\hline Pre-test & 64.09 & 22 & 10.867 & 2.493 & 21 & 0.021 \\
\hline Post-test & 57.82 & 22 & 11.236 & & & \\
\hline
\end{tabular}

Based on table 9 which was taken from the paired-sample t-test result on the experiment group (Facebook collaborative writing), we could see there was a statistically significant difference between the mean score of the pre and post-test in the training group, $t \quad(22)=2.493, \mathrm{p}<0.05$ and (Mean Different=6.273) This resulted to a rejection of the second null hypothesis, where there was a significant difference in mean score between the pre and post-test of the Facebook collaborative writing (experiment group).

\section{ii. Qualitative analysis: semi-structures interview}

Mutual interaction and cognitive conflict

As mentioned in Fung (2010), some of the features may somehow overlap especially when it involves interaction. From the responses given by the students, we could see a combined pattern occurring between mutual interaction and cognitive conflict. This could be seen from the bar chart above where all the responses that fall into the category of mutual interaction were also related to the cognitive conflict.

Some of the respondents responded that the topic given was slightly difficult for a group task. However, they managed to solve the conflict and came into consensus by choosing one person's experience as the storyline of their writing. This shows that the conflict could also offer better assessment and understanding towards the ideas. It also exercised students' creative problem-solution process. They were able to agree upon delegating the task proportionately. This was an evident of how a good management of conflict can arrive at a positive mutual interaction which is a very important feature in collaborative writing (Dale 1997). This is presented by $\mathrm{S} 02$.

Nevertheless, to some students this feature was found difficult to be attained though they had tried to contribute. S04 had expressed her difficulty in working well with the other members.
When there is no mutual consensus reached among the group members, the differing opinions and alternatives shared would usually inflict cognitive conflicts.

In this theme, only one response was found negative. The student commented on the task assigned as difficult as it required them to write a story on one's experience which made them choose to write based on one person's ideas. However, the conflicts heightened during the discussion as some of her group members were not able to digest the idea well and some misinterpreted the intended message.

A mixture feeling of positive and negative was also identified where the student found both pros and cons of this feature in the activity. As identified in the verbatim interview, she used the phrase 'I think' that signified uncertainty and a word 'but' to show contrast.

\section{Negotiation}

Negotiation is one of the collaborative writing features which refers to a process that comprises three kind of negotiation, i) personal, ii) interactive, and iii) procedural. This process involves mostly on ones' or collaborative mental processes restructuring that unite and establish the ideas shared. Most of the responses in this interview fell into the category of interactive negotiations and they are all negatives.

This response from $\mathrm{S} 03$ is categorized under interactive negotiation where the learners were having problems to understand or make their group members understand the message or ideas shared. She said "Because my English not good. I don't know how to tell." (S03) So does another student pointed out that, “...sometime we don't know how to explain." (S04)

\section{Shared expertise}

The collaboration in the writing group seemed to benefit the members in it. It merges students of different proficiency levels and expertise as a group that would contribute to the betterment on the writing produced. The respondents in this study claimed that they learnt from the materials and ideas shared. They even got to learn from their friends' mistakes when discussing openly on the group page.

\section{iii. Qualitative analysis: Open-ended}

The next instrument used to triangulate the findings for this research question is an open-ended response. From one of the open-ended question in the questionnaire, the students were asked on their opinion about the use of Facebook in group essay writing. The responses were collected from 23 students in the experiment group. Based on the open-ended responses in the post-test questionnaire, we could see that the students found the use of Facebook as a medium of collaborative writing as useful and positive in many ways. 
Mutual interaction and cognitive conflict

One of the themes identified is mutual interaction. This is how an agreement reached will facilitate the collaboration among members. This theme was identified based on the statement made by a student B10, "From that we can work together to make a good essay"

Negotiation

Negotiation was one of the least popular features arise in the open-ended. Only two out of three kinds of negotiation were identified: i) personal and ii) procedural.

B13 found that found that the activity contributed to a better mental processing. "It help me to know to write better" and at the same time B07 learned that they could easily discuss important thing "We always discuss important stuff".

\section{Shared expertise}

The most popular theme found in the open-ended response is shared expertise. Many of the students had acknowledged the positive function of Facebook in order to share their knowledge and expertise. B03 for instance admitted that the cooperation built may enhance the quality of their writing and also their team work.

\section{DISCUSSION AND CONCLUSION}

The results of this study have shown us the effects of Facebook on the students' writing apprehension appeared in a mix of positive and negative responses. Nevertheless, the numerous advantages and facilitating features of Facebook to host an active learning environment such as online collaborative writing certainly outdo its limitations as seen in this study.

Since the findings demonstrated both positive and negative feedbacks, this was in line with many researchers on writing apprehension and web 2.0 (Chuo 2007; Khodary; 2012; Supyan et. al. 2011) who had seen affirmative effects on the students" writing apprehension after the use of web 2.0 tools. It was even parallel with Nik Nurni Adilah (2005) who found negative results on her respondents' apprehension evaluation, however, seen positive improvements on the stress and product apprehension level after the online writing intervention.

For its promising effects as cited in many recent researches (de Villiers 2010; Hagit Meishar-Tal, Gila Kurtz, and Efrat Picterse 2012; Kessler, 2009; Mak and Coniam 2008; Safynaz Kazem and Wan Fara Adlina 2012; Woo et. al 2011), Facebook could be integrated in the English language classroom with some modifications and adaptation of tasks and activities especially those concerning ESL collaborative writing activities.

Moreover, this online writing platform is believed to be suitable and cost-effective medium for the current English language classroom teaching as the recent national assessment policy has been revamped to a more comprehensive assessment package. This is also consistent with the aspect of collaborative learning proposed by Dillenbourg (1999) and advantages of collaborative learning in building better and diverse learning knowledge, skills and experience (Astin 1993; Dale 1994; Rau, and Heyl 1990) which could create an informal learning surrounding that can humanize the classroom (Johnson and Johnson 1986).
Therefore, this online approach is in line with the assessment required. Not only that, de Villiers (2010) stated this platform could also be used beyond the classroom and reach wider online resources.

The use of Facebook group in the collaborative writing activity process has also demonstrated a full use of this medium as a discussion wall. This would be able to encourage the ESL students to share expertise and ideas in enhancing all the members' English Language proficiency. The spacious room and other available features in the online SS4D group discussion wall may also provide more opportunities for students to venture into more types of writings. So, the stakeholders who are the students, teachers, and schools could definitely consider this online platform as an alternative pedagogical approach in the ESL classroom especially for activities beyond classroom.

\section{REFERENCES}

[1] Amasha, M., \& Alkhalaf, S. (2014). The effect of using facebook markup language (fbml) for designing an e-learning model in higher education. International Journal of Research in Computer Science, 4 (5) 1-9.

[2] Awani. (2015). UPSR 2015: Pencapaian meningkat, 38,344 calon dapat semua A. Retrieved http://www.astroawani.com/berita-malaysia/upsr-2015pencapaian-me ningkat-38-344- calon-dapat-semua81170

[3] Brown, D. H., (2000). Principles of Language Learning and Teaching 5th ed. United States of America: Pearson Education, Inc All.

[4] Chapman, K. (2006). 20,000 year six pupils can't read and write well. The Star Online. 23 October.

[5] Chitravelu, N., Sithamparam, S., \& Choon, T.S. (2005). ELT Methodology Principles and Practice. Ed ke-2. Shah Alam: Oxford Fajar Sdn. Bhd.

[6] Floyd, R. G., Keith, T. Z., Taub, G. E., \& McGrew, K. S. (2007) Cattell-Horn-Carroll cognitive abilities and their effects on reading decoding skills: $\mathrm{g}$ has indirect effects, more specific abilities have direct effects. School Psychology Quarterly, 22 (2), 200-233.

[7] Jamian, A. R. (2011). The Problems Pertaining To Reading And Writing Skills In Malay Language Among Rural Primary School Children. Malay Language Education Journal (MyLEJ), 1 (1) 1-12.

[8] Kabilan, M. K., Ahmad, N. \& Mohamad Jafre Zainal Abidin, M. J (2010). Facebook: An online environment for learning of English in institutions of higher education?. The Internetand higher education, 13(4), 179-187.

[9] Karal, H., Kokoc, M., \& Cakir, O. (2015). Impact of the educational use of Facebook group on the high school students' proper usage of language. Education and Information Technologies, 1-19.

[10] Kementerian Pendidikan Malaysia. (2012). Pelan pembangunan pendidikan Malaysia

[11] 2013-2025. Kuala Lumpur: Pusat Perkembangan Kurikulum Kementerian Pendidikan Malaysia.

[12] Kementerian Pendidikan Malaysia. (2015). Surat Pekeliling Lembaga Peperiksaan BIL.2 Tahun 2015:Format Peperiksaan Pusat Ujian Pencapaian Sekolah Rendah (UPSR) Tahun 2016. KPMSP.100-1/7/1 (80). Putrajaya: Government Printing.

[13] Mohamad, A. R. (2015). Facebook And Community Of Practice In Higher Education. 1st Global Conference On Technology In Language Learning 2015 (Glit2015). 131-139.

[14] Raman, A. \& Mohamed, A. H. (2013). Issues of ICT Usage among Malaysian Secondary School English Teachers. English Language Teaching, 6 (9) 74-82.

[15] Omar, H., Embi, M. A., \& Yunus, M. M., (2012). ESL Learners' Interaction in an Online Discussion via Facebook. Asian Social Science, 8 (11) 67-74

[16] Prensky, M. (2012). Digital Natives, Digital Immigrants. On the Horizon, 9 (5)

[17] Sani, N. \& Idris, A. R. (2013). Identifying the Challenges Encountered by Teachers in Dealing with Indigenous Participants. Malaysian Online Journal of Educational Management (MOJEM) 1 (3): 48-63.

[18] Sarkar, S. (2012). The Role of Information and Communication Technology (ICT) in Higher Education for the 21st Century. The Science Probe, 1 (1) 30-41. 
[19] Shih, R.C. (2013). Effect Of Using Facebook To Assist English For Business Communication Course Instruction. TOJET: The Turkish Online Journal of Educational Technology, 12 (1), 52-59

[20] Silverman, M. (2015). Leading social networks worldwide as of November 2015, ranked by number of active users (in millions). The Statistics Portal. Retrieved from http://www.statista.com/statistics/272014/global-socialnetworks-ranke d-bynumber-of-

[21] News Strait Times. 2014. UPSR Result: Fewer Straight As this year. Retrieved

from http://www.nst.com.my/news/2015/09/upsr-result-fewer-straight-year.

[22] Thirusanku, J., \& Yunus, M. M. (2014). Status of English in Malaysia. Asian Social Science, 10(14) 254.

[23] Vikneswaran, T., \& Krish, P. (2014). Utilising social networking sites to improve writing: a case study with Chinese students in Malaysia. Technology, Pedagogy and Education, 25(3) 287-300.

[24] Yunus, M. M., (2007). Malaysian ESL teachers' use of ICT in their classrooms: expectations and realities. European Association for Computer Assisted Language Learning, 19 (1) 79-95.

[25] Yunus, M. M. \& Salehi, H. (2012.) The Effectiveness of Facebook Groups on Teaching and Improving Writing: Participants' Perceptions. International Journal Of Education And Information Technologies, 1 (6) 87-96.

[26] Yunus, M. M., Salehi, H., \& Chenzi, C. (2012). Integrating Social Networking Tools into ESL Writing Classroom: Strengths and Weaknesses. English Language Teaching, 5 (8) 42-48.

[27] Yunus, M. M. \& Mat, S. S. (2014). Writing needs and Strategies of FELDA Primary ESL Pupils. Journal of Education and Human Development, 3 (2) 1017-1035.

[28] Yunus, M. M., Lubis, M. A., \& Lin, C.P. (2009). Language Learning via ICT: Uses, Challenges and Issues. Wseas transactions on information science and applications, 9 (6) 1453-1467

\section{Audrey Shalini Ananthan}

Currently works as a teacher in one of the primary school in Malaysia. She also currently studies at Faculty of Education National University of Malaysia (UKM) 43600, Bangi, Selangor, Malaysia.

\section{Nur Ehsan Mohd Said}

He is a lecturer at Faculty of Education, National University of Malaysia. A few of his publication:

Recent research output:

(2019) Using Dictogloss Technique to Enhance Student's Skill in Writing Narrative Text

(2018) English Language Attitude: a case study of science stream and social science stream ESL learners

(2018) ESL Student's Perception of Teacher's Written Feedback Practice in Malaysian Classrooms 